\title{
Belgopeltula belgica (Vincx \& Gourbault, 1992) gen. et comb. nov. and Mudwigglus micramphidium sp. nov. from the west coast of Sweden, and reappraisal of the genus Pseudaraeolaimus Chitwood, 1951 (Nematoda: Araeolaimida: Diplopeltidae)
}

\author{
Oleksandr HOLOVACHOV \\ Department of Zoology, Swedish Museum of Natural History, \\ Box 50007, SE-104 05 Stockholm, Sweden. \\ Email: oleksandr.holovachov@nrm.se \\ urn:lsid:zoobank.org:author:89D30ED8-CFD2-42EF-B962-30A13F97D203
}

\begin{abstract}
Two species of the nematode family Diplopeltidae are described from Skagerrak. The new genus Belgopeltula gen. nov. is proposed for Diplopeltula belgica Vincx \& Gourbault, 1992 and is characterised by: amphidial fovea circular in female and double-loop-shaped in male; excretory pore located at the level of cephalic setae bases; oral opening on the dorsal side of the body; pharynx subdivided into strongly muscularised fusiform corpus and weakly muscularised narrow and long postcorpus; female didelphic with antidromously reflexed ovaries; supplements absent. Mudwigglus micramphidium sp. nov. is characterised by: a body of $0.6 \mathrm{~mm}$ long; cephalic sensilla $1.5 \mu \mathrm{m}$ long; amphidial fovea loop-shaped, $8 \mu \mathrm{m}$ long and $3.5 \mu \mathrm{m}$ wide; gymnostom without cuticularised ring; tail elongate conoid, with subcylindrical distal part; terminal setae absent; spicules $15 \mu \mathrm{m}$ long; gubernaculum present; two midventral precloacal setae. It is distinguished from M. macramphidium Leduc, 2013 in having shorter amphidial fovea, shorter spicules and presence of two precloacal setae. Redescription of Diplopeltis cylindricauda Allgén, 1932 is provided based on type material. Diplopeltula minuta Vitiello, 1972 is transferred to the genus Mudwigglus Leduc, 2013. Diplopeltis cylindricauda Allgén, 1932, Diplopeltula laminata Vitiello, 1972 and Diplopeltula cassidaignensis Vitiello, 1972 are transferred to the genus Pseudaraeolaimus Chitwood, 1951.
\end{abstract}

Keywords. Morphology, new genus, new species, Diplopeltula, taxonomy.

Holovachov O. 2017. Belgopeltula belgica (Vincx \& Gourbault, 1992) gen. et comb. nov. and Mudwigglus micramphidium sp. nov. from the west coast of Sweden, and reappraisal of the genus Pseudaraeolaimus Chitwood, 1951 (Nematoda: Araeolaimida: Diplopeltidae). European Journal of Taxonomy 383: 1-21.

https://doi.org/10.5852/ejt.2017.383

\section{Introduction}

The genus Diplopeltula Gerlach, 1950 was proposed to accommodate two new species, D. breviceps Gerlach, 1950 (type species) and D. longiceps Gerlach, 1950, as well as previously known species Diplopeltis cylindricauda Allgén, 1932 (Allgén 1932; Gerlach 1950). This new genus was placed in the family Diplopeltidae based on the morphology of the amphidial fovea (non-spiral), gubernaculum 
(weakly developed) and caudal glands (opening through three separate outlets). The explicit generic diagnosis was not provided by the author (Gerlach 1950), however, following diagnostic characters of the genus Diplopeltula can be deduced based on the identification key included in the same publication: amphid is loop shaped, with equally long ventral and dorsal branches; amphid not located on the shieldlike cuticular plate. Over the years, many new species were described in Diplopeltula or transferred into it from other genera (Gerlach 1954, 1956; Vitiello 1972; Juario 1974; Boucher \& Helléouët 1977; Jensen 1978), making a total of 23 species by 1992 (Vincx \& Gourbault 1992). Some of these species did not match the original set of diagnostic characters used by Gerlach (1950), e.g. in having amphidial fovea with loop branches of unequal length, or amphid located on the shield-like cuticular plate. As a result, the genus Diplopeltula became very heterogeneous morphologically, making it impossible to propose concise and unambiguous generic diagnosis (Vincx \& Gourbault 1992). This morphological diversity of the genus was discussed in detail by Holovachov et al. (2009), who subdivided Diplopeltula into several distinct morphological groups without taxonomic status, as well as transferred a number of species to the genera Diplopeltoides Gerlach, 1962 (Gerlach 1962) and Pararaeolaimus Timm, 1961 (Timm 1961). A new genus Mudwigglus Leduc, 2013 was proposed within the family Diplopeltidae for three new species as well as one known species, which was originally described in Diplopeltula (Leduc 2013). And most recently, in view of new morphological data, another six species were transferred from the genus Diplopeltula to the genus Diplopeltoides (Holovachov \& Boström 2017). Material, collected recently during the project "Systematics of Swedish free-living nematodes of the orders Desmodorida and Araeolaimida", provides additional information on the morphology and diversity of the species currently assigned to the genus Diplopeltula in particular and of the family Diplopeltidae in general.

\title{
Material and methods
}

Bottom sediment samples were collected in several locations in the southern part of the Skagerrak and in Gullmarn Fjord off the west coast of Sweden. All samples were collected with a bottom dredge or box corer and further sieved in the laboratory before fixation. Nematodes were extracted from samples using a decanting and sieving method (smallest mesh sizes: $45 \mu \mathrm{m}$ or $70 \mu \mathrm{m}$ ). Freshwater was used during sieving to induce osmotic shock in nematodes and separate them from the substrate (Giere 2009). Samples were immediately fixed in 4\% formaldehyde. For light microscopy, formaldehyde-preserved specimens were transferred to pure glycerine using the rapid method of Seinhorst (1959) as modified by De Grisse (1969). Permanent nematode mounts on glass slides were prepared using the paraffin wax ring method. All curved structures were measured along the curved median line. Type and other specimens are deposited in the invertebrate collections of the Department of Zoology, Swedish Museum of Natural History, Stockholm, Sweden (SMNH). Type specimen of Diplopeltis cylindricauda (SMNH Type-3435) from the invertebrate collection of the Swedish Museum of Natural History (Boström \& Holovachov 2017) was included in this study. Abbreviations used in Tables are according to Hunt \& Palomares-Ruis (2012).

\section{Results}

\author{
Phylum Nematoda Potts, 1932 \\ Class Chromadorea Inglis, 1983 \\ Order Araeolaimida De Coninck \& Schuurmans Stekhoven, 1933 \\ Family Diplopeltidae Filipjev, 1918 \\ Genus Belgopeltula gen. nov. \\ urn:1sid:zoobank.org:act:C016D9A9-F945-4320-A549-9180F7E3CF80
}

\section{Type and only species}

Belgopeltula belgica (Vincx \& Gourbault, 1992) gen. et comb. nov. = Diplopeltula belgica Vincx \& Gourbault, 1992 


\section{Diagnosis}

Cuticle transversely striated; striae without ornamentation. Lateral alae absent. Body pores and epidermal glands absent. Somatic sensilla indistinct. Labial region bluntly rounded; lips fused. Inner labial sensilla invisible if present. Outer labial sensilla papilliform, located on the anterior surface of lips. Cephalic sensilla setiform; their bases located at the base of the labial region, anterior to amphid. Subcephalic and cervical sensilla, deirid and ocelli absent. Amphidial fovea unispural (circular) in female and double-loop-shaped in male (starting from the porus amphidialis, fovea extends anteriorly for a short distance, makes a loop towards ventral side of the body and extends posteriorly for the full length of the amphidial fovea, makes another loop towards dorsal side of the body and extends anteriorly almost to the level of the porus amphidialis). Secretory-excretory system present; renette cell located opposite to the anterior part of intestine. Cuticularised secretory-excretory duct very short, opens to the exterior at the level of cephalic setae bases. Oral opening shifted towards the dorsal side of the body. Buccal cavity small and narrow, cheilostom short, remaining part of stoma undifferentiated; its lining is uniform with the lining of the pharynx. Pharyngeal tubes absent. Pharynx subdivided into anterior corpus and posterior postcorpus; corpus fusiform, muscular, with evenly distributed myofilaments; postcorpus narrow and long, weakly muscularised; pharyngeal lumen uniform in thickness along the entire pharynx length; valves absent. Pharyngeal gland orifices penetrate pharyngeal lumen as the base of the stoma. Postcorpus is surrounded by six large pseudocoelomocyles. Female reproductive system didelphic-amphidelphic, with equally developed branches, ovaries reflexed antidromously. Spermatheca present. Vulva equatorial. Vagina straight; pars proximalis vaginae encircled by single sphincter muscle; pars refringens vaginae and epiptygmata absent. Male reproductive system diorchic, testes opposed (anterior testis outstretched, posterior testis reflexed). Spicules symmetrical, arcuate; gubernaculum present. Supplements, precloacal and postcloacal sensilla absent. Three caudal glands present, their cells and nuclei are incaudal. Spinneret present."

\section{Etymology}

The name "Belgopeltula" combines parts of the original binomen: "Belg-" comes from species name belgica, and "-opeltula" - from Genus name Diplopeltula.

\section{Relationships}

The new genus is proposed to accommodate the single species Diplopeltula belgica and is particularly characterised by following unique characters: amphidial fovea circular in female and double-loop-shaped in male; secretory-excretory pore located at the level of cephalic setae bases; oral opening subterminal, located on the dorsal side of the body; pharynx subdivided into strongly muscularised fusiform corpus and weakly muscularised narrow and long postcorpus; female didelphic with antidromously reflexed ovaries; male diorchic with opposed testes; pre- and postcloacal supplements absent.

The morphology of the pharynx in Belgopeltula gen. nov. needs to be clarified. In the original publication, the pharynx is described as: "muscular with an elongated terminal bulb". The drawing shows rather cylindrical anterior part of the pharynx that rapidly widens short distance posterior to the amphideal fovea; the nerve ring is drawn immediately in front of this pharyngeal expansion, at $54 \%$ of the pharynx length. The only other known record of the same species published by Fadeeva \& Mordukhovich (2013) describes the pharynx as follows: "pharynx terminates in a small bulb-like expansion". Nerve ring is not depicted in the figure but is said to encircle pharynx at $77 \%$ of its length.

Videos of the pharyngeal region of the holotype of Diplopeltula belgica were examined. Morphology of the pharynx and surrounding tissues in the holotype confirms well with observations of pharyngeal region in recent specimens: fusiform corpus and narrow postcorpus; large pseudocoelomocyles surrounding anterior part of postcorpus and glandular cells surrounding posterior part of it. Photographs 
of the specimen from the Sea of Japan also show most of the features observed in specimens from the coast of Sweden, despite it being not in the best quality: distinct fusiform corpus and narrower postcorpus; large pseudocoelomocyles surrounding postcorpus along most of its length; basal part of the pharynx surrounded by small glandular cells.

The unique shape of the male amphid (starting from the porus amphidialis, fovea extends anteriorly for a short distance, makes a loop towards ventral side of the body and extends posteriorly for the full length of the amphid, makes another loop towards dorsal side of the body and extends anteriorly almost to the level of the porus amphidialis) separates Belgopeltula gen. nov. from all other genera classified in the family Diplopeltidae (Leduc 2013; Fonseca \& Bezerra 2014), which have unispiral or single loopshaped amphid.

Belgopeltula gen. nov. and Mudwigglus Leduc, 2013 are the only two genera in the family Diplopeltidae with antidromously reflexed ovaries, while the rest of the genera are characterised by outstretched ovaries. In this respect, both genera show similarities to the family Diplopeltoididae Tchesunov, 1990 (Tchesunov 1990) (currently placed in the order Plectida Gadea, 1973 (Gadea 1973)). However, as discussed in Leduc (2013), the morphology of female ovaries (outstretched vs reflexed) may not always be consistent in all species within large taxonomic categories, and in some cases may not have diagnostic value. To make things more complicated, the morphology of female ovaries has not been described in large number of species placed in the genus Diplopeltula, including its type species D. breviceps.

In having oral opening located on the dorsal side of the body, the new genus resembles the genus Campylaimus Cobb, 1920 (Cobb 1920) and some species of the genus Diplopeltula. It can be easily separated from both genera in the morphology of the amphidial fovea (circular in female and characteristic double-loop-shaped in male vs single loop in both females and males in Diplopeltula and Campylaimus), the female reproductive system (ovaries reflexed in Belgopeltula gen. nov. vs ovaries outstretched in Diplopeltula and Campylaimus), the pharynx (subdivided into fusiform corpus and narrow postcorpus in Belgopeltula gen. nov. vs cylindrical in Diplopeltula and Campylaimus) and the position of excretory pore (located at the level of cephalic setae bases in Belgopeltula gen. nov. vs at the level of posterior part of pharynx or anterior part of intestine in Diplopeltula and Campylaimus).

Belgopeltula belgica (Vincx \& Gourbault, 1992) gen. et comb. nov.

Figs 1-2; Table 1

Diagnosis (based on all known populations)

Belgopeltula belgica gen. et comb. nov. is characterised by a body of $0.33-0.55 \mathrm{~mm}$ long; cephalic sensilla setiform, $0.5-4 \mu \mathrm{m}$ long; amphidial fovea sexually dimorphic, circular in female and doubleloop-shaped in male; oral opening located on the dorsal side of the body; secretory-excretory pore located at the level of cephalic setae bases; tail elongate-conoid; ovaries antidromously reflexed; testes opposed; spicules 16-21 $\mu \mathrm{m}$ long, curved, with weakly defined manubrium and subcylindrical shaft; gubernaculum plate-like, with caudal apophysis; supplements absent.

\section{Material examined}

SWEDEN: $2{ }^{\lambda} \partial^{\lambda}, 2$ 우, Skagerrak off the west coast of Sweden, 58 $20^{\prime} 06^{\prime \prime} \mathrm{N}, 11^{\circ} 09^{\prime} 24^{\prime \prime}$ E, muddy sediment from 53 m deep, 9 Aug. 2011, O. Holovachov leg. (SMNH 161699-161701); 1 ठ̊, Skagerrak off the west coast of Sweden, 58 $18^{\prime} 06^{\prime \prime} \mathrm{N}, 11^{\circ} 05^{\prime} 22^{\prime \prime} \mathrm{E}$, mud and gravel from $40-60 \mathrm{~m}$ deep, 9 Aug. 2011 , O. Holovachov leg. (SMNH 161702); $1 \partial^{\lambda}$, Skagerrak off the west coast of Sweden, $58^{\circ} 22^{\prime} 14^{\prime \prime}$ N, $11^{\circ} 05^{\prime} 00^{\prime \prime} \mathrm{E}$, gravel, mud and algae from 30-70 m deep, 9 Aug. 2011, O. Holovachov leg. (SMNH 161703); $3 \delta^{\wedge} \partial^{\lambda}, 3$ 우, Skagerrak off the west coast of Sweden, $58^{\circ} 21^{\prime} 35^{\prime \prime} \mathrm{N}, 11^{\circ} 08^{\prime} 30^{\prime \prime} \mathrm{E}$, fine gravel 


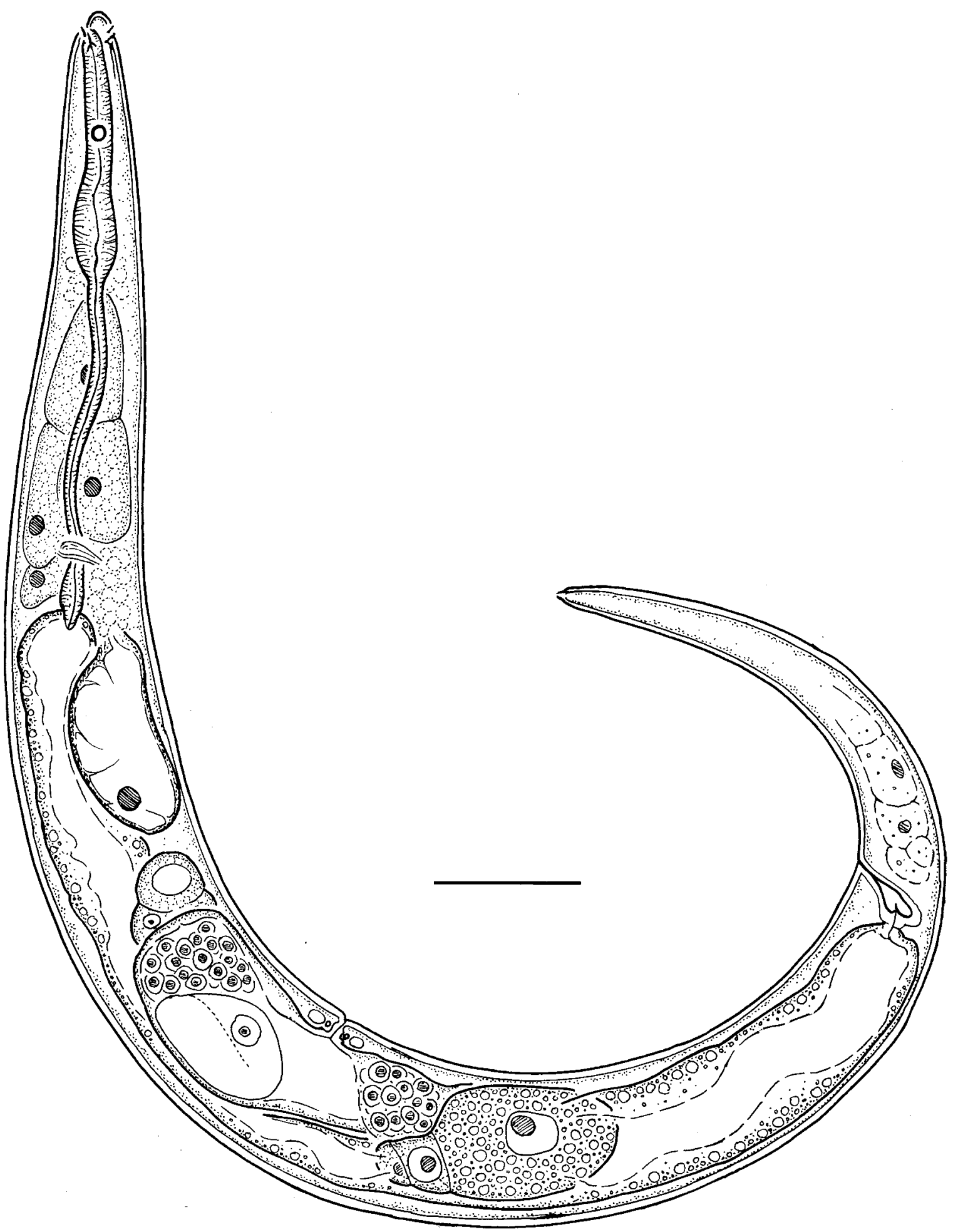

Fig. 1. Belgopeltula belgica (Vincx \& Gourbault, 1992) gen. et comb. nov., female entire view. Scale bar $=20 \mu \mathrm{m}$. 
Table 1. Measurements (in $\mu \mathrm{m}$ ) of Belgopeltula belgica (Vincx \& Gourbault, 1992) gen. et comb. nov., Mudwigglus micramphidium sp. nov. and Pseudaraeolaimus cylindricauda (Allgén, 1932) comb. nov. (presented as mean $\pm \mathrm{SD}$ and (range) where appropriate).

\begin{tabular}{|c|c|c|c|c|c|c|}
\hline \multirow{3}{*}{$\begin{array}{l}\text { Locality } \\
\text { Number of specimens }\end{array}$} & \multicolumn{4}{|c|}{ Belgopeltula belgica } & \multirow{3}{*}{$\begin{array}{c}\begin{array}{c}\text { Mudwigglus } \\
\text { micramphidium } \\
\text { Skagerrak }\end{array} \\
\text { holotype male }\end{array}$} & \multirow{3}{*}{$\begin{array}{c}\begin{array}{c}\text { Pseudaraeolaimus } \\
\text { cylindricauda } \\
\text { Campbell Island }\end{array} \\
\text { lectotype male }\end{array}$} \\
\hline & \multirow{2}{*}{$\begin{array}{l}\text { North Sea } \\
\begin{array}{c}\text { holotype } \\
\text { male }\end{array}\end{array}$} & \multirow{2}{*}{$\frac{\text { Sea of Japan }}{1 \text { male }}$} & \multicolumn{2}{|c|}{ Skagerrak } & & \\
\hline & & & 4 males & 7 females & & \\
\hline Body length & 550 & 381 & $\begin{array}{c}386 \pm 26 \\
(358-418)\end{array}$ & $\begin{array}{c}358 \pm 28 \\
(326-414)\end{array}$ & 594 & 985 \\
\hline Body diameter (BD) & 19 & 21.5 & $\begin{array}{l}18.4 \pm 2.1 \\
(16.0-21.0)\end{array}$ & $\begin{array}{c}25.0 \pm 3.3 \\
(21.5-31.0)\end{array}$ & 17.0 & 19 \\
\hline Pharynx length & 87 & 98 & $\begin{array}{c}98 \pm 6 \\
(91-104)\end{array}$ & $\begin{array}{c}91 \pm 3 \\
(86-96)\end{array}$ & 78 & 133 \\
\hline Tail length & 120 & 74 & $\begin{array}{c}80 \pm 2 \\
(79-82)\end{array}$ & $\begin{array}{c}71 \pm 3 \\
(67-78)\end{array}$ & 66 & 93 \\
\hline $\begin{array}{l}\text { Anal body diameter } \\
\text { (ABD) }\end{array}$ & 18 & 14 & $\begin{array}{c}14.8 \pm 1.5 \\
(13.5-16.5)\end{array}$ & $\begin{array}{l}13.1 \pm 1.8 \\
(11.0-16.5)\end{array}$ & 14.0 & 18 \\
\hline $\mathrm{a}$ & 28.9 & 17.7 & $\begin{array}{c}21.1 \pm 2.1 \\
(18.1-22.8)\end{array}$ & $\begin{array}{l}14.4 \pm 1.4 \\
(13.1-16.9)\end{array}$ & 34.7 & 51.8 \\
\hline $\mathrm{b}$ & 6.3 & 3.9 & $\begin{array}{l}4.0 \pm 0.1 \\
(3.9-4.0)\end{array}$ & $\begin{array}{l}4.0 \pm 0.3 \\
(3.7-4.6)\end{array}$ & 7.6 & 7.4 \\
\hline $\mathrm{c}$ & 4.6 & 5.2 & $\begin{array}{l}4.8 \pm 0.3 \\
(4.6-5.2)\end{array}$ & $\begin{array}{l}5.0 \pm 0.3 \\
(4.7-5.4)\end{array}$ & 8.9 & 10.6 \\
\hline c' & 6.7 & 5.3 & $\begin{array}{l}5.4 \pm 0.4 \\
(5.0-5.8)\end{array}$ & $\begin{array}{l}5.5 \pm 0.7 \\
(4.7-6.7)\end{array}$ & 4.7 & 5.2 \\
\hline $\mathrm{V}$ or $\mathrm{T}(\%)$ & $?$ & $?$ & $\begin{array}{c}35.7 \pm 2.0 \\
(34.2-37.1)\end{array}$ & $\begin{array}{c}49.4 \pm 1.8 \\
(47.1-52.3)\end{array}$ & 48.7 & 59.3 \\
\hline Labial region diameter & $?$ & $?$ & $\begin{array}{l}5.7 \pm 1.0 \\
(4.0-6.5)\end{array}$ & $\begin{array}{l}6.7 \pm 0.7 \\
(6.0-8.0)\end{array}$ & 8.0 & 5.5 \\
\hline Oral opening from ant. end & $?$ & $?$ & $\begin{array}{l}2.1 \pm 0.6 \\
(1.5-3.0)\end{array}$ & $\begin{array}{l}2.7 \pm 0.7 \\
(2.0-3.5)\end{array}$ & apical & apical \\
\hline Cephalic setae length & 4 & 1.5 & $\begin{array}{l}1.0 \pm 0.3 \\
(0.5-1.5)\end{array}$ & $\begin{array}{l}0.8 \pm 0.3 \\
(0.5-1.5)\end{array}$ & 1.5 & 7.0 \\
\hline $\begin{array}{l}\text { Amphidial fovea from } \\
\text { ant. end }\end{array}$ & 18 & 19.7 & $\begin{array}{c}18.0 \pm 0.9 \\
(17.0-19.0)\end{array}$ & $\begin{array}{c}19.1 \pm 1.9 \\
(16.5-22.0)\end{array}$ & 11.5 & 5.5 \\
\hline $\begin{array}{l}\text { Amphidial fovea length } \\
(\max )\end{array}$ & 26 & 37 & $\begin{array}{c}15.9 \pm 2.1 \\
(13.5-18.5)\end{array}$ & $\begin{array}{l}2.6 \pm 0.7 \\
(1.5-3.5)\end{array}$ & 8.0 & 11.0 \\
\hline Amphidial fovea width & 4 & 4 & $\begin{array}{l}4.3 \pm 0.8 \\
(3.5-5.0)\end{array}$ & $\begin{array}{l}2.6 \pm 0.7 \\
(1.5-3.5)\end{array}$ & 3.5 & 3.5 \\
\hline Nerve ring from ant. end & 47 & 76 & $?$ & $?$ & 50 & 95 \\
\hline $\begin{array}{l}\text { Nerve ring from anterior } \\
\text { end as \% of pharynx } \\
\text { length }\end{array}$ & 54 & 77 & $?$ & $?$ & 64 & 71 \\
\hline Excretory pore from ant. end & subapical & $?$ & subapical & subapical & 66 & 12.5 \\
\hline $\begin{array}{l}\text { Secretory-excretory pore } \\
\text { from ant. end as \% of } \\
\text { pharynx length }\end{array}$ & subapical & $?$ & subapical & subapical & 85 & 9 \\
\hline Vagina or spicules length & 21 & 16.5 & $\begin{array}{l}17.4 \pm 0.8 \\
(16.5-18.0)\end{array}$ & $\begin{array}{l}4.9 \pm 0.9 \\
(4.0-6.5)\end{array}$ & 15.0 & 17 \\
\hline $\begin{array}{l}\text { Rectum or gubernaculum } \\
\text { length }\end{array}$ & 9 & 4.1 & $\begin{array}{l}7.1 \pm 0.7 \\
(6.5-8.0)\end{array}$ & $\begin{array}{l}11.0 \pm 1.5 \\
(9.0-13.5)\end{array}$ & 6.0 & 8.0 \\
\hline Vagina length / BD & - & - & - & $\begin{array}{c}0.2 \\
(0.1-0.3)\end{array}$ & - & - \\
\hline Rectum or spicules / ABD & - & - & $\begin{array}{l}1.1 \pm 0.1 \\
(1.1-1.2)\end{array}$ & $\begin{array}{l}0.8 \pm 0.1 \\
(0.7-1.0)\end{array}$ & 1.1 & 0.9 \\
\hline
\end{tabular}




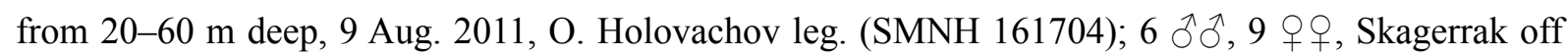
the west coast of Sweden, 58 $8^{\circ} 58^{\prime \prime} \mathrm{N}, 11^{\circ} 10^{\prime} 05^{\prime \prime} \mathrm{E}$, coarse gravel from 30-50 m deep, 9 Aug. 2011, O. Holovachov leg. (SMNH 161705-161707).

\section{Description}

\section{Adult}

Body fusiform in female and cylindrical in male, tapering anteriorly in the pharyngeal region and posteriorly in the tail region, ventrally curved upon fixation. Cuticle finely striated along entire body, striae without longitudinal incisures or any other ornamentation visible under the light microscope. Somatic setae indistinct if present. Labial region rounded, lips fused. Inner and outer labial sensilla not observed. Cephalic sensilla small setiform, equal to 0.1-0.2 labial region diameters in length, their bases are located 3-7 $\mu \mathrm{m}$ from anterior end. Amphidial fovea dissimilar in shape and size between sexes (see descriptions of each sex). Oral opening shifted towards the dorsal side of the body, $1.5-3.5 \mu \mathrm{m}$ from the anterior end. Stoma very small, cheilostom short, remaining part of stoma undifferentiated, its lining is uniform with the lining of the pharynx. Pharynx distinctly subdivided into anterior corpus and posterior postcorpus; corpus slightly fusiform, muscular; postcorpus narrow and long. Pharyngeal gland nuclei indistinct. Pharyngeal gland orifices penetrate pharyngeal lumen at the base of the stoma. Postcorpus is surrounded by six large pseudocoelomocytes, two cells arranged longitudinally in three body sectors: dorsal, right-subventral and left-subventral. Nerve ring is located at the posterior end of the pharynx, its exact position if obscured by small glandular cells (neuron bodies?). Secretory-excretory system present; renette cell located opposite to the ventral side of the anterior part of intestine; secretory-excretory pore opens to the exterior just posterior to cephalic setae bases. Tail elongate-conoid. Caudal glands and spinneret present.

\section{Female}

Amphidial fovea unispiral (circular). Reproductive system didelphic, amphidelphic; ovary branches symmetrical, antidromously reflexed. Anterior ovary situated to either right or left of intestine; posterior ovary situated to either right or left of intestine. Spermathecae present, filled with round spermathozoa. Vulva located at mid-body. Vagina straight, pars proximalis vaginae surrounded by a sphincter muscle; pars refringens vaginae absent. Intrauterine egg not seen. Rectum short.

\section{Male}

Amphidial fovea double-loop-shaped: starting from the porus amphidialis, fovea extends anteriorly for a short distance, makes a loop towards ventral side of the body and extends posteriorly for the full length of the amphid, makes another loop towards dorsal side of the body and extends anteriorly almost to the level of the porus amphidialis. Amphid length (longest) to width ratio is 2.7-5.2. Narrow space between amphidial branches not refractive and not ornamented. Reproductive system diorchic, anterior testis outstretched; posterior testis reflexed. Spicules paired and symmetrical, weakly curved, with weakly defined manubrium and subcylindrical shaft. Gubernaculum plate-like, with strong dorsocaudal apophysis. Supplements and caudal setae indistinct or absent.

\section{Remarks}

Both published descriptions of Diplopeltula belgica are each based on single male specimens (Vincx \& Gourbault 1992; Fadeeva \& Mordukhovich 2013); females of this species were unknown until now. Recent male specimens resemble type male from the North Sea (Vincx \& Gourbault 1992) in structure of amphid, digestive (see above) and excretory systems, with the exception of the following: shorter body (358-418 $\mu \mathrm{m}$ in recent specimens vs $550 \mu \mathrm{m}$ in type male), shorter amphid (13.5-18.5 $\mu \mathrm{m}$ in recent specimens vs $26 \mu \mathrm{m}$ in type male), shorter cephalic setae $(0.5-1.5 \mu \mathrm{m}$ in recent specimens vs $4 \mu \mathrm{m}$ in type male), shorter (16.5-18 $\mu \mathrm{m}$ in recent specimens vs $21 \mu \mathrm{m}$ in type male) and less curved (weakly arcuate in recent specimens vs strongly arcuate in type male) spicules. 


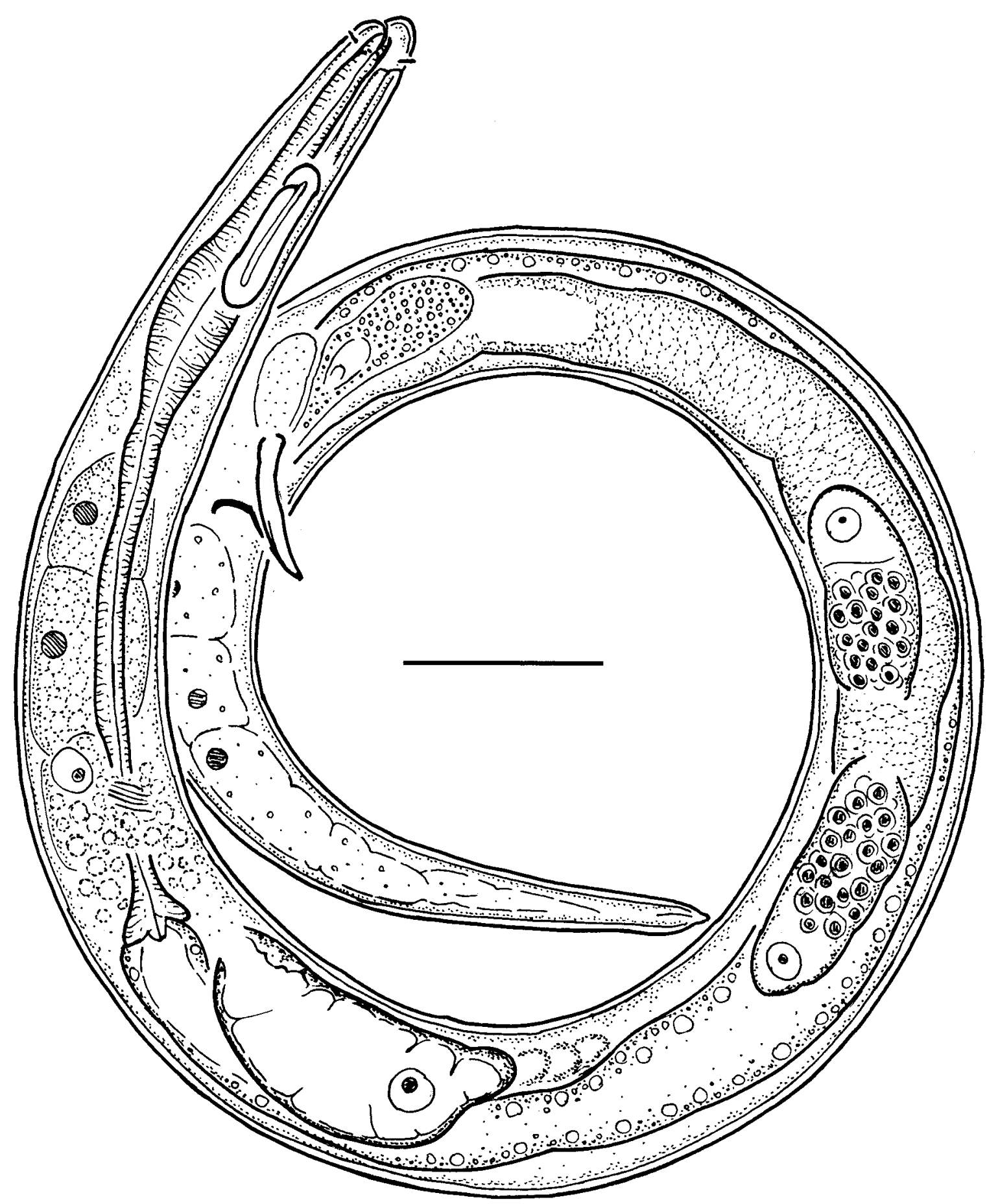

Fig. 2. Belgopeltula belgica (Vincx \& Gourbault, 1992) gen. et comb. nov., male entire view. Scale bar $=20 \mu \mathrm{m}$. 
Specimen from the Sea of Japan (Fadeeva \& Mordukhovich 2013) is closer in size to specimens from Skagerrak (Table 1) - the only substantial differences are the length of the amphidial fovea (13.5$18.5 \mu \mathrm{m}$ in recent specimens vs $37 \mu \mathrm{m}$ in the male from the Sea of Japan) and less curved (weakly arcuate in recent specimens vs strongly arcuate in the male from the Sea of Japan) spicules.

Greatest discrepancies between all three populations are in the assumed position of the nerve ring and the morphology of male gonad. In the original description, the nerve ring is drawn short distance behind the amphid, at $54 \%$ of the pharynx length (Vincx \& Gourbault 1992). Male specimen from the Sea of Japan is described to have the nerve ring at $77 \%$ of the pharynx length (Fadeeva \& Mordukhovich 2013), but it is not drawn on the figure. In recent specimens, the position of the nerve ring can not be identified with confidence, and further observations are required to clarify this. Regarding the morphology of the male gonad, type specimen is said to have both testes outstretched (Vincx \& Gourbault 1992), while our observations clearly show that the posterior testis in this species is reflexed posteriad.

\section{Type species}

Genus Mudwigglus Leduc, 2013

Mudwigglus patumuka Leduc, 2013

Diagnosis (emended after Leduc 2013)

Cuticle transversely striated; striae without ornamentation. Lateral alae absent. Body pores and epidermal glands present. Somatic sensilla present. Labial region bluntly rounded; lips fused. Inner labial sensilla invisible if present. Outer labial sensilla papilliform, located on the anterior surface of lips. Cephalic sensilla setiform; their bases located at the base of the labial region, anterior to amphid. Subcephalic and cervical sensilla, deirid and ocelli absent. Amphidial aperture loop-shaped (inverted U-shaped). Secretory-excretory system present; renette cell located opposite to the posterior part of the pharynx and anterior part of intestine. Cuticularised secretory-excretory duct very short, opens to the exterior at the level of the posterior part of pharynx. Oral opening apical. Buccal cavity small but distinctly subdivided into three sections: cheilostom narrow tubular; gymnostom barrel-shaped or truncate conoid, with weakly cuticularised walls; stegostom short conoid, its lining is uniform with the lining of the pharynx. Pharyngeal tubes absent. Pharynx subdivided into anterior corpus and posterior bulbus; corpus cylindrical, muscular, with evenly distributed myofilaments; bulbus muscular; pharyngeal lumen uniform in thickness along the entire pharynx length; valves absent. Dorsal gland orifice penetrates pharyngeal lumen at the base of the stoma, ventrosublateral gland orifices indistinct. Dorsal gland nucleus is visible in the basal bulbus. Female reproductive system didelphicamphidelphic with equally developed branches, ovaries antidromously reflexed. Spermatheca absent. Vulva equatorial. Vagina straight or oblique; pars proximalis vaginae encircled by single sphincter muscle; pars refringens vaginae and epiptygmata absent. Male reproductive system diorchic; anterior testis outstretched, posterior testis outstretched, with posteriorly reflexed terminal section of the germinal zone. Spicules symmetrical, arcuate; gubernaculum present. Supplements and precloacal sensilla present. Setae in caudal region of males arranged in subventral and subdorsal pairs along the tail. Three caudal glands present, their nuclei are incaudal. Caudal glands open separately via three pores (this structure is obscure in some species).

\section{Valid species}

Mudwigglus macramphidium Leduc, 2013

Mudwigglus micramphidium sp. nov.

Mudwigglus minutus (Vitiello, 1972) comb. nov.

= Diplopeltula minuta Vitiello, 1972

Mudwigglus nellyae (Vincx \& Gourbault, 1992) 
= Diplopeltula nellyae Vincx \& Gourbault, 1992

Mudwigglus patumuka Leduc, 2013

Mudwigglus plebeius Leduc, 2013

\title{
Nomenclatorial change
}

Diplopeltula minuta Vitiello, 1972 is here transferred to the genus Mudwigglus based on its close morphological affinities to $M$. plebeius, from which it can only be separated by features of male accessory apparatus (one or two setae in M. minutus vs one setae and two tubular supplements in M. plebeius).

\author{
Mudwigglus micramphidium sp. nov. \\ urn:1sid:zoobank.org:act:C5028B8C-5860-45B6-A1D0-DBF6E1B30ED2
}

Fig. 3; Table 1

\section{Diagnosis}

Mudwigglus micramphidium sp. nov. is characterised by a body of $0.6 \mathrm{~mm}$ long; cephalic sensilla $1.5 \mu \mathrm{m}$ long; amphidial fovea an inverted U-shape, $8 \mu \mathrm{m}$ long and $3.5 \mu \mathrm{m}$ wide; gymnostom without cuticularised ring; tail elongate conoid, with subcylindrical distal part; terminal setae absent; spicules $15 \mu \mathrm{m}$ long; gubernaculum present; two midventral precloacal setae.

\section{Etymology}

The specific epithet refers to the overall similarity between the new species and M. macramphidium, as well as one of the major differences between these two species (amphid size).

\section{Material examined}

\section{Holotype}

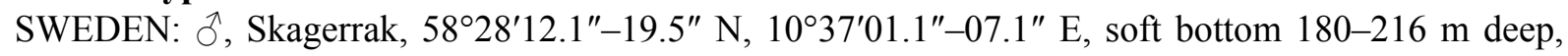
10 Oct. 2012, "Inventering Bratten" leg. (SMNH Type-8889).

\section{Description}

\section{Adult male}

Body cylindrical, tapering posteriorly in the tail region, strongly ventrally curved upon fixation. Cuticle finely striated along the entire body, annules without longitudinal striation or any other ornamentation visible under the light microscope. Somatic setae present, sparsely distributed over entire body, with one ventrosublateral pair in the pharyngeal region just posterior to nerve ring, and three pairs along the tail: one dorsosublateral pair short distance posterior to cloacal opening, one ventrosublateral pair at about the middle of tail length, and one sublateral pair close to tail terminus. Labial region truncate conoid; lips fused. Inner and outer labial sensilla not observed. Cephalic sensilla small setiform, equal to 0.2 labial region diameters in length, their bases are located $5 \mu \mathrm{m}$ from anterior end. Amphidial fovea an inverted U-shape with its dorsal branch slightly longer $(8 \mu \mathrm{m})$ than ventral branch $(6.5 \mu \mathrm{m})$. Amphidial fovea length (longest) to width ratio is 2.2. Narrow space between amphidial branches not refractive and not ornamented. Distinct cell with large nucleus is located behind the amphid, and is connected to amphidial fovea. Stoma very small, but distinctly subdivided into three sections: cheilostom narrow tubular, $3 \mu \mathrm{m}$ long; gymnostom truncate conoid, narrowing towards anterior end, with weakly cuticularised walls, $3 \mu \mathrm{m}$ long and $2 \mu \mathrm{m}$ wide, without cuticularised ring; stegostom very short conoid, its lining is uniform with the lining of the pharynx. Pharynx distinctly subdivided into anterior corpus and posterior basal bulbus; corpus subcylindrical, muscular; basal bulbus ovoid, muscular. Dorsal pharyngeal gland nucleus located in the basal bulbus; dorsal pharyngeal glad orifice penetrates pharyngeal lumen at the base of the stoma. Ventrosublateral pharyngeal gland nuclei and orifices indistinct. Nerve ring encircling 
pharynx at posterior third of its length. Secretory-excretory system present; renette cell located opposite to the ventral side of the basal bulbus and anterior part of the intestine; secretory-excretory pore opens to the exterior at level of the basal bulbus. Reproductive system diorchic; anterior testis outstretched, posterior testis outstretched, with posteriorly reflexed terminal section of the germinal zone. Large spermatogonia are visible. Spicules paired and symmetrical, arcuate, with weakly developed manubrium

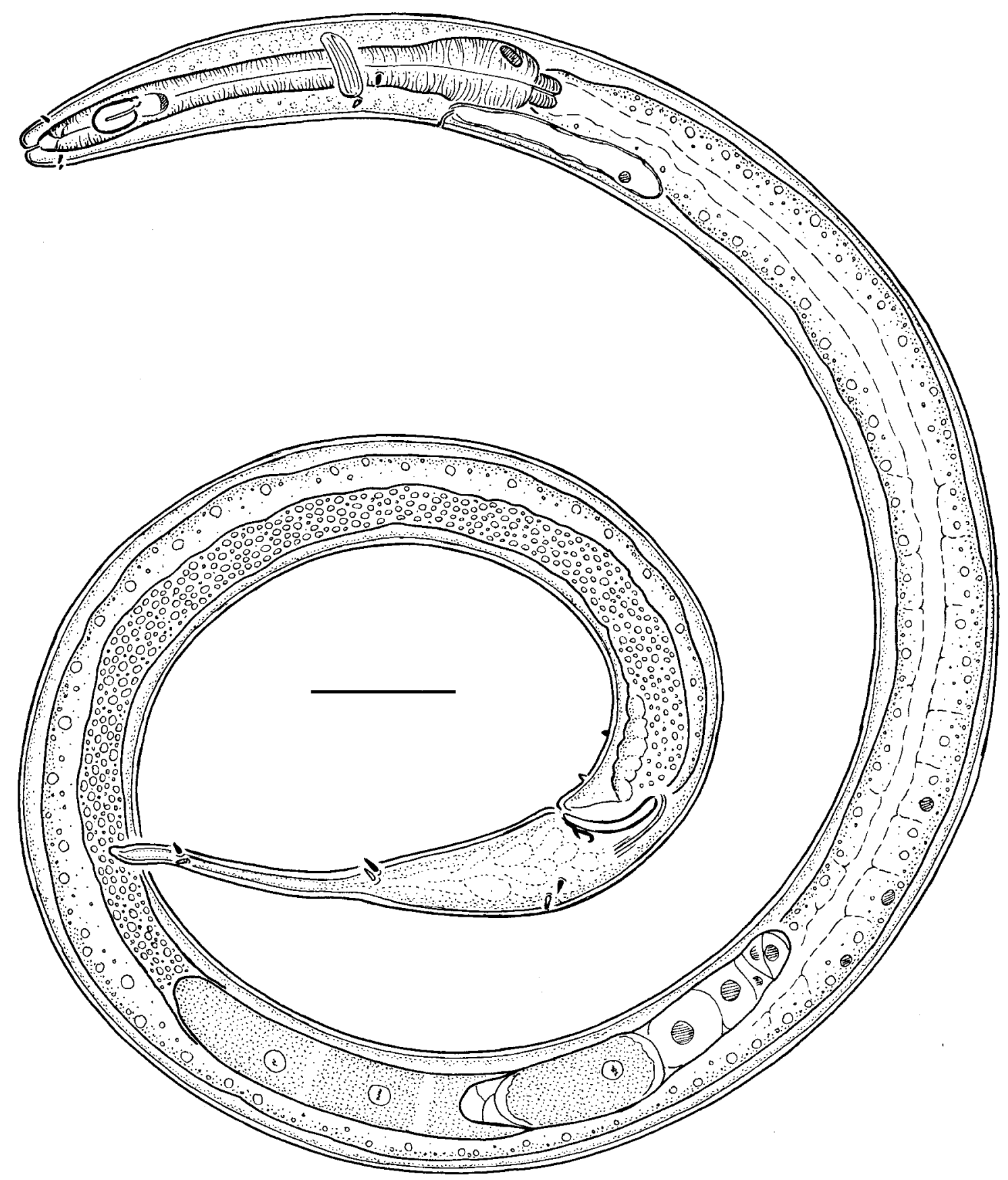

Fig. 3. Mudwigglus micramphidium sp. nov., holotype male (SMNH Type-8889) entire view. Scale $\mathrm{bar}=20 \mu \mathrm{m}$. 
and subcylindrical shaft. Gubernaculum present, platelike. Male accessory apparatus composed of two midventral precloacal setiform sensilla. Tail elongate conoid, subcylindrical distally. Terminal setae absent. Caudal glands and their outlets obscure.

\section{Female}

Not found.

\section{Remarks}

Mudwigglus micramphidium sp. nov. closely resembles $M$. macramphidium described from New Zealand (Leduc 2013) in general body size (Table 2), shape and length of the tail and absence of gubernaculum apophysis. The new species can be separated from M. macramphidium in having shorter amphid (amphid length/width ratio 2.2 in M. micramphidium sp. nov. vs 3.5 in M. macramphidium), shorter spicules (15 $\mu \mathrm{m}$ in M. micramphidium sp. nov. vs $23-25 \mu \mathrm{m}$ in M. macramphidium), male accessory apparatus (two precloacal setae in M. micramphidium sp. nov. vs one precloacal setae and two tubular supplements in M. macramphidium).

\section{Key to species of Mudwigglus Leduc, 2013}

See Table 2 for additional diagnostic characters.

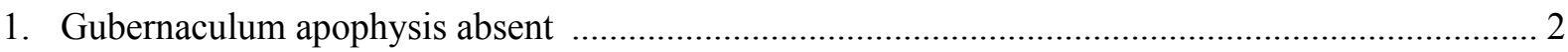

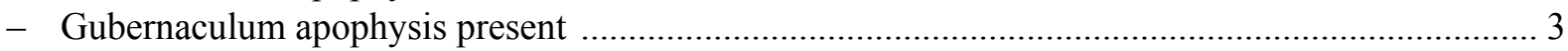

2. Amphid length/width ratio 3.5; spicules $23-25 \mu \mathrm{m}$ long ................ macramphidium Leduc, 2013

- Amphid length/width ratio 2.2; spicules $15 \mu \mathrm{m}$ long M. micramphidium sp. nov.

3. Tail conoid with clavate tip; c'-ratio $>3$ . .4

- Tail cylindrical with bluntly rounded tip; c'-ratio $<3$ 5

4. Males with one precloacal setae and two tubular supplements M. plebeius Leduc, 2013

- Males with one or two precloacal setae, tubular supplements absent M. minutus (Vitiello, 1972) comb. nov.

5. Body longer than $0.7 \mathrm{~mm}$; spicules $31-37 \mu \mathrm{m}$; vagina oblique M. patumuka Leduc, 2013

- Body shorter than $0.4 \mathrm{~mm}$; spicules $16-23 \mu \mathrm{m}$; vagina perpendicular M. nellyae (Vincx \& Gourbault, 1992)

Genus Pseudaraeolaimus Chitwood, 1951

\section{Type species}

Pseudaraeolaimus perplexus Chitwood, 1951

Diagnosis (emended after Fonseca \& Bezerra 2014)

Cuticle visually smooth or finely striated; striae without ornamentation. Lateral alae absent. Somatic sensilla present. Labial region rounded; lips fused. Inner and outer labial sensilla indistinct. Cephalic sensilla setiform; their bases located at the base of the labial region, anterior to amphidial fovea. Cervical (paramphidial) sensilla present, located at the level of the amphid and posterior to it. Deirid absent. Ocelli present or absent. Amphidial fovea loop-shaped (inverted U-shaped). Secretory-excretory system present; renette cell located opposite to the anterior part of intestine. Cuticularised secretory-excretory duct very short, opens to the exterior just posterior to cephalic setae bases. Oral opening apical. Buccal 
Table 2. Selected diagnostic characters of species of the genus Mudwigglus Leduc, 2013 based on literature data supplemented with recent observations.

\begin{tabular}{|c|c|c|c|c|c|c|}
\hline Characters & M. patumuka & M. nellyae & M. plebejus & M. minutus & M. macramphidium & $\begin{array}{c}\text { M. micramphidium } \\
\text { sp. nov. }\end{array}$ \\
\hline $\begin{array}{l}\text { Body length } \\
(\mathrm{mm})\end{array}$ & $0.79-0.95$ & $0.28-0.31$ & $0.46-0.68$ & $0.38-0.53$ & $0.60-0.76$ & 0.59 \\
\hline Tail length $(\mu \mathrm{m})$ & $52-63$ & $20-33$ & $39-65$ & $44-50$ & $54-69$ & 66 \\
\hline c' ratio & $1.8-2.7$ & $1.3-2.4$ & $2.8-4.3$ & $3.8-4.4$ & $3.5-4.6$ & 4.7 \\
\hline $\begin{array}{l}\text { Amphidial fovea } \\
\text { length/width ratio }\end{array}$ & 2.5 & 2.0 & 2.0 & $2.3-2.7$ & 3.5 & 2.2 \\
\hline Vagina shape & oblique* & straight** & oblique & $\mathrm{NA}^{* * *}$ & straight & NA \\
\hline $\begin{array}{l}\text { Spicule length } \\
(\mu \mathrm{m})\end{array}$ & $31-37$ & $16-23$ & $18-26$ & 16 & $23-25$ & 15 \\
\hline $\begin{array}{l}\text { Gubernaculum } \\
\text { apophysis }\end{array}$ & present & present & present & present & absent & absent \\
\hline $\begin{array}{l}\text { Precloacal } \\
\text { supplements }\end{array}$ & $3-4$ & 2 & 2 & 0 & 2 & 0 \\
\hline Precloacal setae & 1 & 1 & 1 & 2 & 1 & 2 \\
\hline Terminal setae & 3 & 3 & 2 & 2 & 0 & 0 \\
\hline
\end{tabular}

* - at an oblique angle to the body axis

** - at a straight angle to the body axis

*** - not available, females are unknown

cavity small and undifferentiated, its lining is uniform with the lining of the pharynx. Pharyngeal tubes absent. Pharynx subdivided into anterior corpus and posterior postcorpus; corpus cylindrical, muscular, with evenly distributed myofilaments; postcorpus glandular; pharyngeal lumen uniform in thickness along the entire pharynx length; valves absent. Female reproductive system didelphic-amphidelphic with equally developed branches, ovaries outstretched. Vulva equatorial. Male reproductive system diorchic, anterior testis outstretched, posterior testis outstretched, with posteriorly reflexed terminal section of the germinal zone. Spicules symmetrical, arcuate; gubernaculum present. Precloacal sensillum present. Setae in caudal region of males arranged in subventral and subdorsal pairs along the tail. Three caudal glands present, their nuclei are incaudal. Spinneret present.

\section{Valid species}

Pseudaraeolaimus cassidaigniensis (Vitiello, 1972) comb. nov.

= Diplopeltula cassidaigniensis Vitiello, 1972

Pseudaraeolaimus cylindricauda (Allgén, 1932) comb. nov.

= Diplopeltis cylindricauda Allgén, 1932

= Diplopeltula cylindricauda (Allgén, 1932)

Pseudaraeolaimus laminata (Vitiello, 1972) comb. nov.

= Diplopeltula laminata Vitiello, 1972

Pseudaraeolaimus perplexus Chitwood, 1951

Pseudaraeolaimus ocellatus Kito, 1981 


\section{Remarks}

According to Tchesunov \& Miljutina (2008), main diagnostic characters of the genus Pseudaraeolaimus include: terminal (apical) oral opening, amphidial fovea loop-shaped, stoma small undifferentiated, pharynx glandular in its posterior part, excretory pore close to anterior end, ovaries paired, gubernaculum without apophyses. In addition, both Pseudaraeolaimus perplexus and P. ocellatus have several pairs of strongly developed cervical setae. This last feature is also known in other genera of Diplopeltidae, such as Araeolaimus de Man, 1888, Diplopeltis Cobb in Stiles \& Hassall, 1905, Metaraeolaimoides De Coninck, 1936 and Southerniella Allgén, 1932, but not in type species of the genus Diplopeltula, D. breviceps.

\section{Nomenclatorial changes}

1) Diplopeltula cassidaigniensis Vitiello, 1972 is transferred to the genus Pseudaraeolaimus based on presence of terminal oral opening, undifferentiated stoma, loop-shaped amphidial fovea, strongly developed cervical setae.

2) Diplopeltis cylindricauda Allgén, 1932 is transferred to the genus Pseudaraeolaimus based on presence of terminal oral opening, undifferentiated stoma, loop-shaped amphidial fovea, strongly developed cervical setae, excretory pore close to anterior end (Fig. 4).

3) Diplopeltula laminata Vitiello, 1972 is transferred to the genus Pseudaraeolaimus based on presence of terminal oral opening, undifferentiated stoma, loop-shaped amphidial fovea, strongly developed cervical setae.

Pseudaraeolaimus cylindricauda (Allgén, 1932) comb. nov.

Fig. 4; Table 1

\section{Diagnosis}

Pseudaraeolaimus cylindricauda comb. nov. is characterised by a body of $1 \mathrm{~mm}$ long; cephalic sensilla $7 \mu \mathrm{m}$ long; amphidial fovea an inverted U-shape, $11 \mu \mathrm{m}$ long and $3.5 \mu \mathrm{m}$ wide; two pairs of cervical setae at level with amphidial fovea and 4-5 pairs at level with midpharynx; ocelli absent; tail subcylindrical; spicules $17 \mu \mathrm{m}$ long.

\section{Material examined}

NEW ZEALAND: Campbell Island: lectotype $ð$ (SMNH Type-3435).

\section{Description}

\section{Adult male}

Body cylindrical, tapering posteriorly in the tail region, strongly ventrally curved upon fixation. Cuticle finely striated along the entire body, striae without longitudinal incisures or any other ornamentation visible under the light microscope. Somatic setae (except cervical setae, see below) are indistinct. Labial region truncate conoid; lips fused. Inner and outer labial sensilla not observed. Cephalic sensilla setiform, equal to 1.3 labial region diameters in length, their bases are located $1.5 \mu \mathrm{m}$ from anterior end. Amphidial fovea an inverted U-shape with its dorsal branch slightly longer $(11 \mu \mathrm{m})$ than ventral branch $(10.5 \mu \mathrm{m})$. Amphidial fovea length (longest) to width ratio is 3.1. Narrow space between amphidial branches not refractive and not ornamented. Stoma very small, undifferentiated, its lining is uniform with the lining of the pharynx. Pharynx poorly preserved, cylindrical along most of its length. Pharyngeal glands and nuclei indistinct. Nerve ring encircling pharynx at posterior third of its length. Secretory-excretory system present; renette cell located opposite to the ventral side of the and anterior part of the intestine; secretoryexcretory pore opens to the exterior at level with the amphid. Reproductive system diorchic; anterior testis outstretched, posterior testis outstretched, with posteriorly reflexed terminal section of the germinal zone. 
Spicules paired and symmetrical, arcuate, with rounded manubrium and conoid shaft. Gubernaculum present, plate-like and without apophyses. Male accessory apparatus composed of single midventral precloacal papilliform sensillum. Tail subcylindrical. Caudal glands obscure, spinneret present.

\section{Female}

Not available.

\section{Key to species of Pseudaraeolaimus Chitwood, 1951}

See Table 3 for additional diagnostic characters.

1. Body $2 \mathrm{~mm}$ long; amphidial fovea with transverse striation

P. laminata (Vitiello, 1972) comb. nov.

- Body shorter than $1.5 \mathrm{~mm}$ long; amphidial fovea without transverse striation

2. Ocelli present P. ocellatus Kito, 1981

- Ocelli absent 3

3. Amphidial fovea a broad loop, less than 1.5 times long as it is wide ...P. perplexus Chitwood, 1951

- Amphidial fovea a narrow loop, more than 3 times long as it is wide
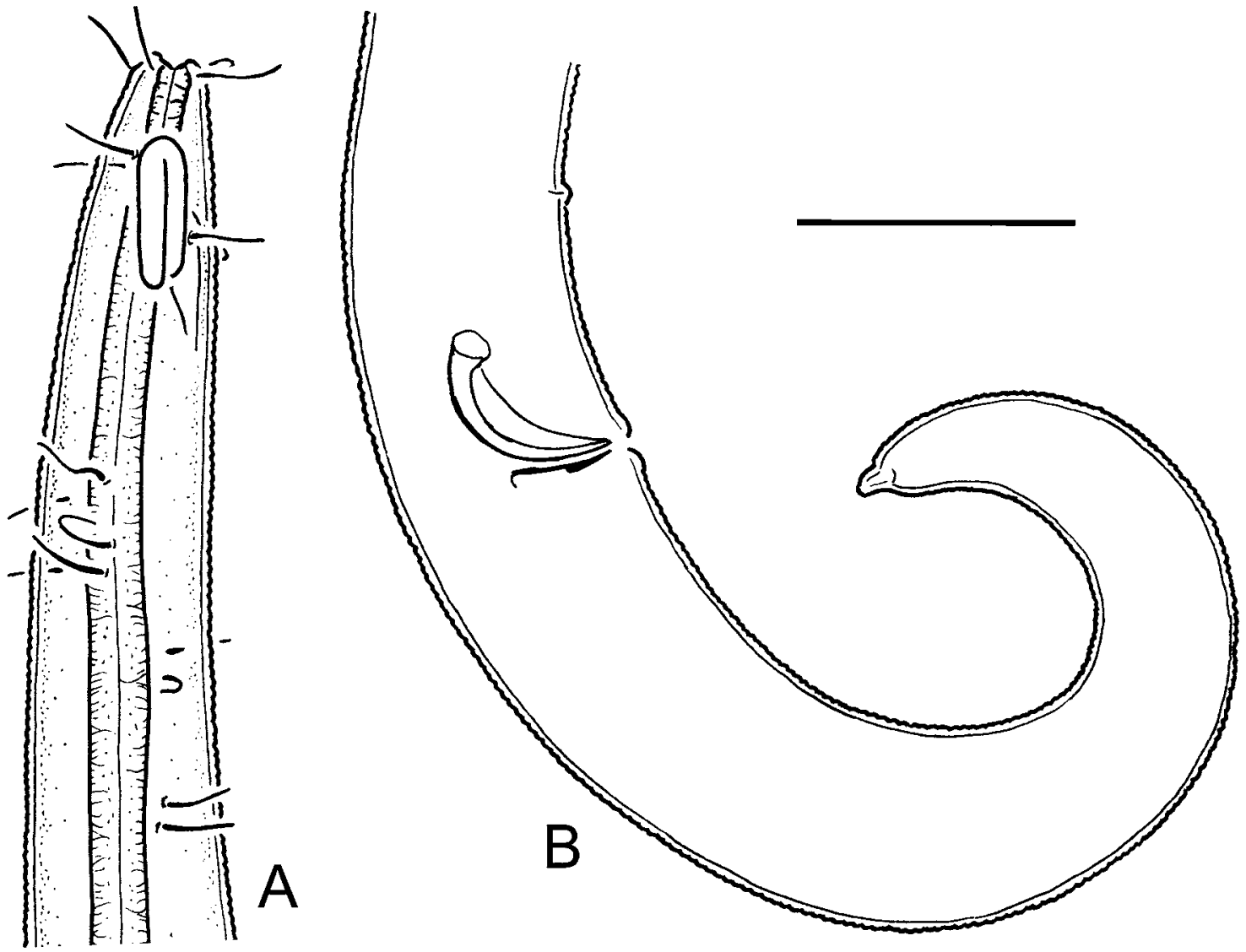

Fig. 4. Pseudaraeolaimus cylindricauda (Allgén, 1932) comb. nov. lectotype male (SMNH Type-3435). A. Anterior end. B. Posterior end. Scale bar $=20 \mu \mathrm{m}$. 
Table 3. Selected diagnostic characters of species of the genus Pseudaraeolaimus Chitwood, 1951 based on literature data supplemented with recent observations.

\begin{tabular}{|c|c|c|c|c|c|}
\hline Characters & P. perplexus & P. ocellatus & P. cylindricauda & P. laminata & P. cassidaigniensis \\
\hline Body length (mm) & $1.08-1.20$ & $0.77-0.93$ & 0.99 & 2.09 & 1.36 \\
\hline $\begin{array}{l}\text { Amphidial fovea } \\
\text { shape }\end{array}$ & broad loop & narrow loop & narrow loop & narrow loop & narrow loop \\
\hline Amphid striation & absent & absent & absent & present & absent \\
\hline Ocelli & absent & present & absent & absent & absent \\
\hline Cervical setae & two pairs & five pairs & 6-7 pairs & six pairs & two pairs \\
\hline Spicule length $(\mu \mathrm{m})$ & 14 & $18-19$ & 17 & 30 & NA* \\
\hline $\begin{array}{l}\text { Gubernaculum } \\
\text { apophysis }\end{array}$ & absent & absent & absent & present & NA \\
\hline $\begin{array}{l}\text { Precloacal } \\
\text { supplements }\end{array}$ & 1 & 1 & 1 & $?$ & NA \\
\hline
\end{tabular}

* - not available, specimens of particular sex are unknown

4. Cervical setae short, only two pairs at level with amphidial fovea

..P. cassidaigniensis (Vitiello, 1972) comb. nov.

- Cervical setae long, two pairs at level with amphidial fovea and 4-5 pairs at level with midpharynx P. cylindricauda (Allgén, 1932) comb. nov.

\section{Family Diplopeltidae Filipjev, 1918}

Diagnosis (emended after Fonseca \& Bezerra 2014)

Cuticle visually smooth, finely striated or coarsely annulated. Lateral alae absent. Somatic sensilla present. Inner and outer labial sensilla papilliform. Cephalic sensilla setiform; their bases located at the base of the labial region, anterior to amphidial fovea. Cervical (paramphidial) sensilla present in some genera, located at the level of the amphid and posterior to it. Deirid absent. Ocelli present or absent. Amphidial fovea unispiral or loop-shaped. Secretory-excretory system present. Oral opening apical or shifted either to dorsal or ventral body side. Buccal cavity tubular, cylindrical or undifferentiated. Teeth-like structures absent. Pharynx variable in shape; pharyngeal lumen uniform in thickness along the entire pharynx length; valves absent. Female reproductive system didelphic-amphidelphic or monodelphic-prodelphic. Ovaries outstretched or reflexed antidromously. Male reproductive system diorchic. Posterior testis is either anteriorly oriented and reflexed in the anterior section (reflexed terminal section of the germinal zone) or is posteriorly directed. Spicules symmetrical; gubernaculum present. Precloacal sensilla present in some genera. Three caudal glands present, their nuclei are incaudal. Caudal glands open separately via three pores, or together via a common spinneret.

\section{Valid genera}

Araeolaimus de Man, 1888

$=$ Araeolaimoides de Man, 1893

= Coinonema Cobb, 1920

= Parachromagaster Allgén, 1929

Belgopeltula gen. nov. 
Campylaimus Cobb, 1920

Cylindrolaimus de Man, 1880

Diplopeltis Cobb in Stiles \& Hassal, 1905

= Dipeltis Cobb, 1891

= Discophora Villot, 1875

Diplopeltula Gerlach, 1950

Edalonema Andrássy, 2007

= Adelonema Holovachov \& Sturhan, 2003

Intasia Tchesunov \& Miljutina, 2008

Metaraeolaimoides De Coninck, 1936

Morlaxia Vincx \& Gourbault, 1988

Mudwigglus Leduc, 2013

Pararaeolaimus Timm, 1961

Pseudaraeolaimus Chitwood, 1951

Southerniella Allgén, 1932

\section{Key to genera of Diplopeltidae}

See Table 4 for additional diagnostic characters.

1. Amphidial fovea a transverse slit; cuticle with ten longitudinal ridges ....Edalonema Andrássy, 2007

- Amphidial fovea double-loop-shaped in male, unispiral in female Belgopeltula gen. nov.

- Amphidial fovea unispiral 2

- Amphidial fovea loop-shaped

2. Basal bulb absent; freshwater or terrestrial

Cylindrolaimus de Man, 1880

- Basal bulb present; marine 3

3. Single anterior ovary

Intasia Tchesunov \& Miljutina, 2008

- Two ovaries (anterior and posterior) Southerniella Allgén, 1932

4. Oral opening shifted to the ventral body side Morlaxia Vincx \& Gourbault, 1988

- Oral opening apical or shifted to the dorsal body side 5

5. Basal pharyngeal bulb present; ovaries antidromously reflexed Mudwigglus Leduc, 2013

- Basal pharyngeal bulb absent; ovaries outstretched 6

6. Lateral alae present, in some species fused with the ventral limb of the amphid

Campylaimus Cobb, 1920

- Lateral alae absent 7

7. Amphid in a shape of rounded loop 8

- Amphid in a shape of elongated loop 10

8. Anterior body region abruptly narrowing; amphid at a distance equal to more than five labial region diameters from the anterior end Metaraeolaimoides De Coninck, 1936

- Anterior body region cylindrical or subcylindrical; amphid at a distance equal to less than two labial region diameters from the anterior end

9. Buccal cavity cup-shaped; pronounced sexual dimorphism in the amphid size (large in males and small in females) Pararaeolaimus Timm, 1961 
苞

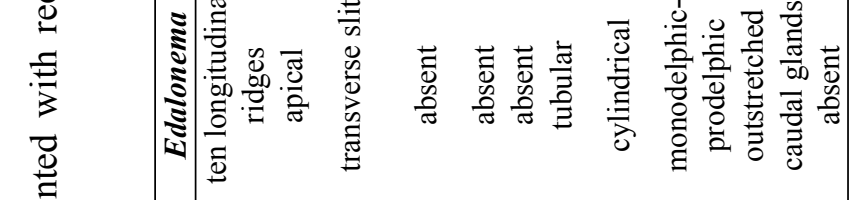

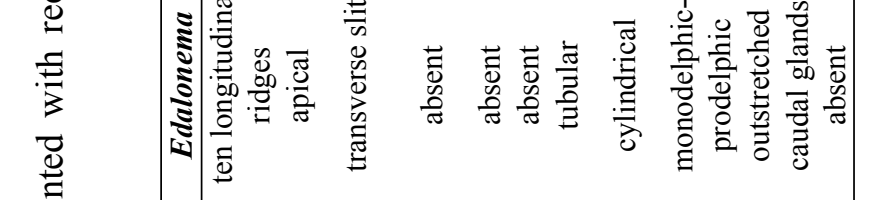

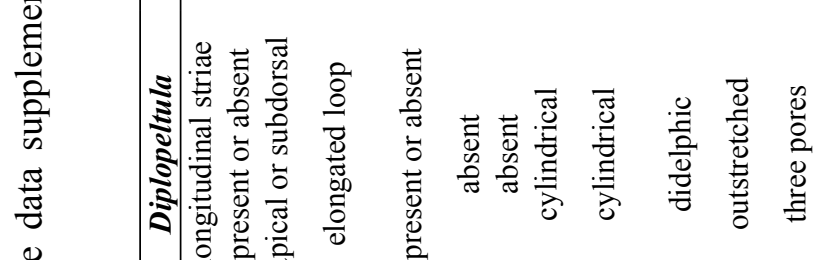

药

莺

б

芠

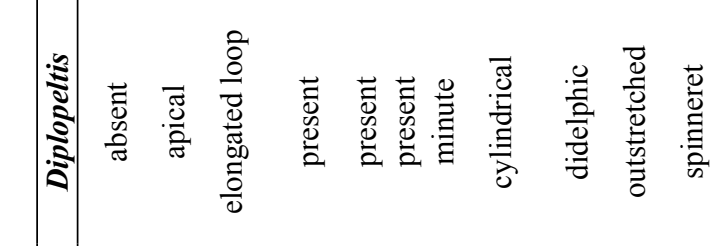

$\stackrel{\infty}{2}$

.

:

章

龸

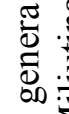

品

竞

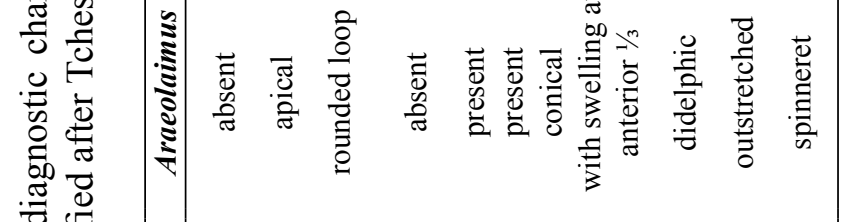

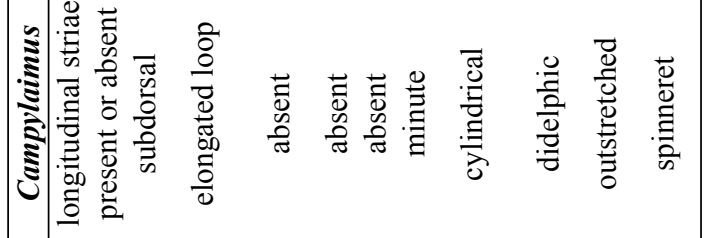

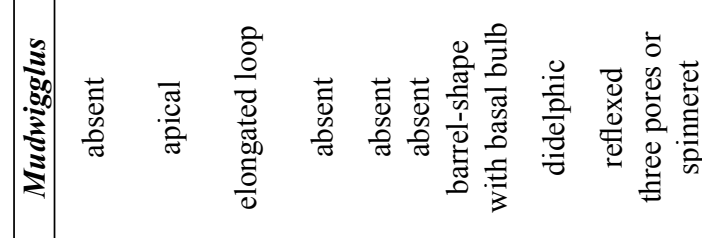

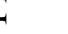

?

送

昶

$+$

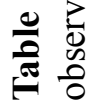

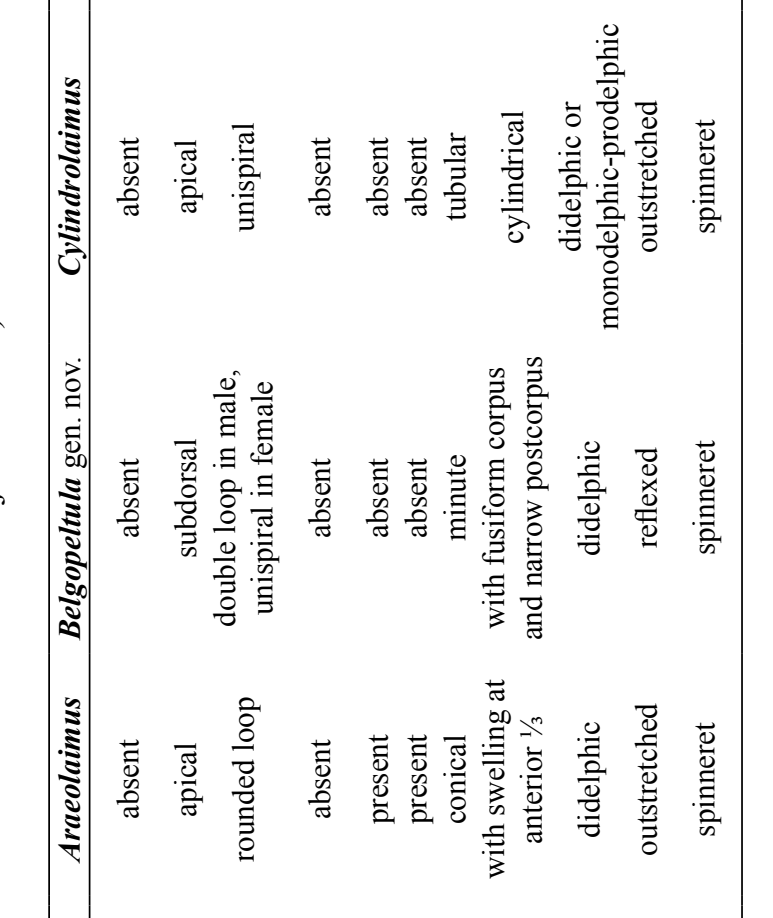

HIIII/|

Ir IIII)

IIIIIIIn|

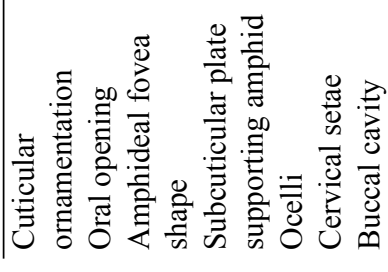

离

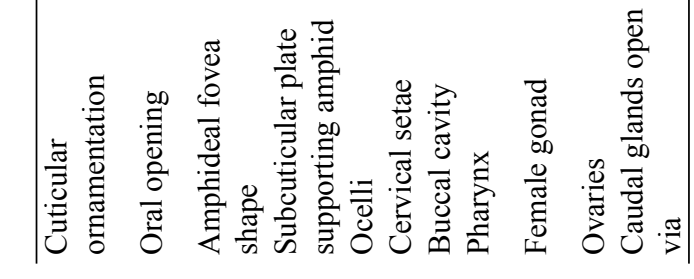


- Buccal cavity conical; no sexual dimorphism in the amphid size Araeolaimus de Man, 1888

10. Cervical (paramphideal) setae absent; caudal glands open via three separate pores

Diplopeltula Gerlach, 1950

- Cervical (paramphideal) setae present; caudal glands open via common spinneret

11. Amphid located on a well-developed refractive subcuticular plate

Diplopeltis Cobb in Stiles \& Hassal, 1905

- Refractive subcuticular plate absent Pseudaraeolaimus Chitwood, 1951

\section{Discussion}

The family Diplopeltidae currently includes 14 genera (including newly described Belgopeltula gen. nov.) and about 120 species (Leduc 2013; Fonseca \& Bezerra 2014). Most of the genera are unequivocally defined and easily identifiable, while the genus Diplopeltula is a morphological and taxonomic "hodgepodge" used to hold species that did not fit the diagnoses of other taxa of this family. As discussed in Holovachov et al. (2009), several factors are at play here. First of all, the description of the type species of the genus Diplopeltula, D. breviceps is brief and does not include many features that are now considered to be diagnostic (structure of the pharynx, excretory system, female reproductive system). Second, many species assigned to Diplopeltula are either described based on specimens of one sex, of which those based on males are prevalent, or the descriptions, even if based on specimens from both sexes, do not include data on the morphology of female reproductive system and other taxonomically important characters. The third factor mentioned in Vincx \& Gourbault (1992) is "rather wide generic diagnosis", or more like an absence of proper generic diagnosis in the original description (Gerlach 1950) or subsequent revision of the group (Gerlach 1962; Vitiello 1972; Vincx \& Gourbault 1992). Last, but not least, type material of $D$. breviceps was not kept and therefore cannot be re-examined because S. Gerlach did not make permanent slides until 1964 (F. Riemann, in littera 10 Apr. 2001). Consequently, until D. breviceps can be recollected from the type locality and properly redescribed, the taxonomy of the genus Diplopeltula will remain unclear.

\section{Acknowledgments}

This research was supported by two grants from the Swedish Taxonomy Initiative: "Taxonomy and distribution of free-living nematodes of the order Plectida in Sweden" and "Systematics of Swedish free-living nematodes of the orders Desmodorida and Araeolaimida". Sampling in the Skagerrak was conducted using vessels ("Skagerak" and "Oscar von Sydow") and facilities of the Sven Lovén Centre for Marine Sciences in Kristineberg. The author wishes to thank Wim Bert and Dominick Verschelde (Ghent University, Belgium) and Natalia Fadeeva (Far Eastern Federal University, Russia) for providing videos and photographs of specimens described as Diplopeltula belgica.

\section{References}

Allgén C. 1932. Weitere Beiträge zur Kenntnis der marinen Nematodenfauna der Campbell-insel. Nyt Magazin for Naturvidenskaberne 70: 97-198.

Boström S. \& Holovachov O. 2017. The Swedish marine nematologist Carl Allgén (1886-1960): a biobibliography and his collection. Zootaxa 4232: 451-490. https://doi.org/10.11646/zootaxa.4232.4.1

Boucher G. \& Helléouët M. 1977. Nématodes des sables fins infralittoraux de la Pierre Noire (Manche occidentale). III. Araeolaimida et Monhysterida. Bulletin du Muséum national d'Histoire naturelle 297: $85-122$. 
Cobb N.A. 1920. One hundred new nemas. (Type species of 100 new genera). Contributions to a Science of Nematology 9: 217-343.

De Grisse A.T. 1969. Redescription ou modifications de quelques techniques utilisées dans l'étude des nématodes phytoparasitaires. Mededelingen Rijksfakulteit Landbouwwetenschappen Gent 34: 351-369.

Fadeeva N. \& Mordukhovich V. 2013. Some new and poorly known nematode species from the Sea of Japan. Deep-Sea Research II 86-87: 119-123. https://doi.org/10.1016/j.dsr2.2012.07.044

Fonseca G. \& Bezerra T.N. 2014. 7.15 Order Araeolaimida De Coninck \& Schuurmans Stekhoven, 1933. In: Schmidt-Rhaesa A. (ed) Handbook of Zoology. Gastrotricha, Cycloneuralia, Gnathifera. Volume 2: Nematoda: 467-486. de Gruyter, Göttingen.

Gadea E. 1973. Sobre la filogenia interna de los Nematodos. Publicaciones del Instituto de Biología Aplicada 54: 87-92.

Gerlach S.A. 1950. Die Diplopeltiden, eine Gruppe freilebender Nematoden. Kieler Meeresforschungen 7: 138-156.

Gerlach S.A. 1954. Nématodes marins libres des eaux souterraines littorales de Tunisie et d'Algérie. Vie et Milieu 4: 221-237.

Gerlach S.A. 1956. Diagnosen neuer Nematoden aus der Kieler Bucht. Kieler Meeresforschungen 12: 85-109.

Gerlach S.A. 1962. Freilebende Meeresnematoden von den Malediven. Kieler Meeresforschungen 18: 81-108.

Giere O. 2009. Meiobenthology. The Microscopic Motile Fauna of Aquatic Sediments. 2nd edition. Springer-Verlag, Berlin \& Heidelberg. https://doi.org/10.1007/978-3-540-68661-3

Holovachov O. \& Boström S. 2017. Three new and five known species of Diplopeltoides (Nematoda, Diplopeltoididae) from Sweden, and a revision of the genus. European Journal of Taxonomy 369: 1-35. https://doi.org/10.5852/ejt.2017.369

Holovachov O., Tandingan De Ley I., Mundo-Ocampo M., Gingold R. \& De Ley P. 2009. Nematodes from the Gulf of California. Part 3. Three new species of the genus Diplopeltoides Gerlach, 1962 (Nematoda: Diplopeltoididae) with overviews of the genera Diplopeltis Gerlach, 1962 and Diplopeltula Gerlach, 1950. Russian Journal of Nematology 17: 43-57.

Hunt D.J \& Palomares-Ruis E. 2012. General morphology and morphometrics of plant-parasitic nematodes. In: Manzanilla-López R.H. \& Marbán-Mendoza N. (eds) Practical Plant Nematology: 2564. Mundi-Prensa, Madrid.

Jensen P. 1978. Four nematoda Araeolaimida from Öresund, Denmark, with remarks on the oesophageal structure in Aegialoalaimus. Cahiers de Biologie marine 19: 221-231.

Juario J.V. 1974. New free-living nematodes from the sublittoral zone of the German Bight. Veröffentlichungen des Instituts für Meeresforschung in Bremerhaven 14: 275-303.

Leduc D. 2013. Mudwigglus gen. n. (Nematoda: Diplopeltidae) from the continental slope of New Zealand, with description of three new species and notes on their distribution. Zootaxa 3682: 351-370. https://doi.org/10.11646/zootaxa.3682.2.8

Seinhorst J.W. 1959. A rapid method for the transfer of nematodes from fixative to anhydrous glycerin. Nematologica 4: 67-69. https://doi.org/10.1163/187529259X00381 
Tchesunov A.V. 1990. A critical analysis of the family Aegialoalaimidae (Nematoda, Chromadoria), trends in evolutionary development of marine nematode pharynx and a proposal of two new families. Zoologicheskii Zhurnal 69: 5-18.

Tchesunov A.V. \& Miljutina M.A. 2008. A new free-living nematode Intasia monohystera gen. n., sp. n. (Nematoda, Araeolaimida, Diplopeltidae) from the Barents Sea and the White Sea, with a key to genera of Diplopeltidae. Russian Journal of Nematology 16: 33-48.

Timm R.W. 1961. The marine nematodes of the Bay of Bengal. Proceedings of the Pakistan Academy of Sciences 1: 1-88.

Vincx M. \& Gourbault N. 1992. Six new species of the genus Diplopeltula (Nematoda: Diplopeltidae) with remarks on the heterogeneity of the taxon. Hydrobiologia 230: 165-178.

https://doi.org/10.1007/BF00036563

Vitiello P. 1972. Sur quelques espèces de Diplopeltula (Nematoda, Araeolaimida). Vie et Milieu 21: 535-544.

Manuscript received: 8 February 2017

Manuscript accepted: 16 June 2017

Published on: 19 December 2017

Topic editor: Rudy Jocqué

Desk editor: Pepe Fernández

Printed versions of all papers are also deposited in the libraries of the institutes that are members of the EJT consortium: Muséum national d'Histoire naturelle, Paris, France; Botanic Garden Meise, Belgium; Royal Museum for Central Africa, Tervuren, Belgium; Natural History Museum, London, United Kingdom; Royal Belgian Institute of Natural Sciences, Brussels, Belgium; Natural History Museum of Denmark, Copenhagen, Denmark; Naturalis Biodiversity Center, Leiden, the Netherlands; Museo Nacional de Ciencias Naturales-CSIC, Madrid, Spain; Real Jardín Botánico de Madrid CSIC, Spain. 